\title{
Mechanisms of endothelial cell swelling from lactacidosis studied in vitro
}

\author{
S. BEHMANESH AND O. KEMPSKI \\ Institute for Neurosurgical Pathophysiology, Johannes Gutenberg-University, \\ 55101 Mainz, Germany
}

Received 20 September 1999; accepted in final form 12 April 2000

\begin{abstract}
Behmanesh, S., and O. Kempski. Mechanisms of endothelial cell swelling from lactacidosis studied in vitro. Am $J$ Physiol Heart Circ Physiol 279: H1512-H1517, 2000.- One of the early sequelae of ischemia is an increase of circulating lactic acid that occurs in response to anaerobic metabolism. The purpose of the present study was to investigate whether lactic acidosis can induce endothelial swelling in vitro under closely controlled extracellular conditions. Cell volume of suspended cultured bovine aortic endothelial cells was measured by use of an advanced Coulter technique employing the "pulse area analysis" signal-processing technique (CASY1). The isosmotic reduction of $\mathrm{pH}$ from 7.4 to 6.8 had no effect on cell volume. Lowering of $\mathrm{pH}$ to $6.6,6.4$, or 6.0 , however, led to significant, $\mathrm{pH}$-dependent increases of cell volume. Swelling was more pronounced in bicarbonate-buffered media than in HEPES buffer. Specific inhibition of $\mathrm{Na}^{+} / \mathrm{H}^{+}$exchange by ethylisopropylamiloride completely prevented swelling in HEPES-buffered media. Pretreatment with ouabain to partially depolarize the cells did not affect the degree of acidosisinduced swelling. In bicarbonate-buffered media, the inhibition of transmembrane $\mathrm{HCO}_{3}^{-}$transport by DIDS reduced swelling to a level comparable with that seen in the absence of bicarbonate ions. Lactacidosis-induced endothelial swelling, therefore, is a result of intracellular $\mathrm{pH}$ regulatory mechanisms, namely, $\mathrm{Na}^{+} / \mathrm{H}^{+}$exchange and bicarbonate-transporting carriers.
\end{abstract}

lactacidosis; bovine aortic endothelial cells; $\mathrm{pH}$ regulation

CAPILLARY DIAMETERS under pathophysiological conditions may be reduced below those of the traversing undeformed red and white blood cells (16) and, therefore, may jeopardize cell passage through the microcirculation as well as nutritive blood flow. The major cause of the reduction of capillary patency is endothelial swelling, as observed in hemorrhagic shock $(14,16)$ or systemic blood acidosis, but not at low flow conditions per se (15). Swelling in these experiments could be prevented by amiloride analogs, as an indication that a $\mathrm{Na}^{+} / \mathrm{H}^{+}$exchanger (NHE) participates in the swelling process. NHEs have been widely studied as membrane mechanisms involved in the regulation of intracellular $\mathrm{pH}\left(\mathrm{pH}_{\mathrm{i}}\right)$ and are present in endothelial cells $(4,10)$. Five NHE isoforms (NHE1-NHE5) represent the major acid-extruding transporters in the ab-

\footnotetext{
Address for reprint requests and other correspondence: $O$. Kempski, Institute for Neurosurgical Pathophysiology, Johannes Gutenberg-Univ., 55101 Mainz, Germany (E-mail: kempski @nc-patho.klinik.uni-mainz.de).
}

sence of bicarbonate $\left(\mathrm{HCO}_{3}^{-}\right)$. In vivo, however, $\mathrm{HCO}_{3}^{-}$ is usually available, and $\mathrm{HCO}_{3}^{-}$-dependent systems contribute to $\mathrm{pH}_{\mathrm{i}}$ regulation; among these, the $\mathrm{Na}^{+}$dependent $\mathrm{Cl}^{-} / \mathrm{HCO}_{3}^{-}$exchanger (NCBE) has been found activated in acidosis in bovine aortic endothelium (4). In addition, $\mathrm{Na}^{+}-\mathrm{HCO}_{3}^{-}$cotransport is activated in corneal endothelium $(1,2,10) . \mathrm{Na}^{+}$-independent $\mathrm{Cl}^{-} / \mathrm{HCO}_{3}^{-}$exchange $(\mathrm{CBE})$ is known to maintain $\mathrm{pH}_{\mathrm{i}}$ after alkalinization. All three systems can be inhibited by DIDS.

There are very few in vitro studies concerned with cell-volume homeostasis of endothelial cells. Those available mostly deal with mechanisms involved in cell-volume regulation after exposure to osmotic stress (e.g., 11, 19, 23). In other cell types such as glia, swelling mechanisms during extracellular acidosis have been studied in detail $(9,12,20,22,24)$. The purpose of the current in vitro study was, therefore, to evaluate the postulated swelling effect of extracellular lactacidosis on endothelial cell volume under closely controlled extracellular conditions and to characterize the transport systems involved.

\section{MATERIALS AND METHODS}

Cell culture. Bovine aortic endothelial (BAE) cells (Stanford University) (5) were maintained as monolayers in petri dishes with the use of DMEM containing $25 \mathrm{mmol} / \mathrm{H} \mathrm{HCO}_{3}^{-}$, $10 \%$ bovine fetal calf serum (FCS), $100 \mathrm{IU} / \mathrm{ml}$ penicillin $\mathrm{G}$, and $50 \mu \mathrm{g} / \mathrm{ml}$ streptomycin. The cells were cultured at $37^{\circ} \mathrm{C}$ in humidified room air containing $5 \% \mathrm{CO}_{2}$. Subcultivation was performed 2-3 times/wk by washing with physiological saline and trypsinization (0.05\% trypsin and $0.02 \%$ EDTA). They were subsequently suspended in medium containing FCS for inactivation of trypsin. After centrifugation, the cells were again washed in physiological saline to remove FCS. For experiments, cells were used once they had reached a confluent stage, usually 5-6 days after subcultivation. To investigate endothelial cell swelling, suspended cells were then transferred into an incubation chamber, which allowed for close control of the extracellular environment (12, 13, 24). The chamber was equipped with two apertures for measurement of $\mathrm{pH}$ and temperature by respective electrodes. A gas-permeable silicon rubber tubing within the chamber served as a membrane oxygenator, providing cells with a

\footnotetext{
The costs of publication of this article were defrayed in part by the payment of page charges. The article must therefore be hereby marked "advertisement" in accordance with 18 U.S.C. Section 1734 solely to indicate this fact.
} 
mixture of $\mathrm{O}_{2}, \mathrm{CO}_{2}$, and $\mathrm{N}_{2}$ for experiments with $\mathrm{HCO}_{3}^{-}$ buffering or with $\mathrm{O}_{2}$ and $\mathrm{N}_{2}$ in HEPES-buffered experiments. A magnetic stirrer prevented cell sedimentation.

To confirm results obtained with BAE cells, endothelial cells from human umbilical cord were used. They were prepared by use of modifications of established methods (8). Briefly, the vessel was mounted on a proximal cannula to clear the clotted blood from the lumen, using medium 199. The other end of the vessel was then connected to a distal cannula. The luminal surface of the vessel was treated with collagenase (type IV, $0.1 \%$ in phosphate-buffered saline) for $15 \mathrm{~min}$ at $37^{\circ} \mathrm{C}$. The endothelial cells were removed by flushing the vessel with medium 199. Endothelial cells from primary culture were grown in medium 199 , which contained $25 \mathrm{mmol} / / \mathrm{HCO}_{3}^{-}, 10 \% \mathrm{FCS}, 100 \mathrm{IU} / \mathrm{ml}$ penicillin $\mathrm{G}, 50 \mu \mathrm{g} / \mathrm{ml}$ streptomycin, and $1 \%$ endothelial cell growth factor.

Measurement of cell volume. Cell volume was determined by CASY1 technology (Coulter technique employing the "pulse area analysis" signal-processing technique; Schärfe System, Reutlingen, Germany) (24). It combines an established particle measurement technique, the "resistance measuring principle," with the pulse area analysis signal-processing technique. For measurement, the suspended cells are introduced into the measuring cell through a capillary of predefined geometry at a constant-stream velocity. During the measurement, a current is supplied to the capillary via two platinum electrodes. The capillary filled with electrolytes has a defined electrical resistance. While passing the capillary, the cells displace electrolyte solution in proportion to cell volume. Because intact cells have isolation properties, resistance along the capillary rises. The measuring signal is scanned by CASY1 at a frequency of $1 \mathrm{MHz}$. CASY1 captures the amplitude and width of the pulse and determines the integral of the measuring signal (pulse area analysis). This procedure allows for measurements with a dynamic range of $>1: 32,000$ in volume. To store this wide volume range with high resolution, a multichannel analyzer with 512,000 volume-linear channels is used. Each of 512,000 registers contains the number of cells that have produced the corresponding pulse area value while passing through the measuring pore. From this volume-linear original size distribution, a diameter-linear size distribution with a resolution level of 1,024 channels is computed. All subsequent measuring parameters are determined on the basis of this size distribution.

Experimental groups. Experiments were performed after a 20-min control period utilized for baseline measurements of cell volume, cell viability, and medium osmolality at an extracellullar $\mathrm{pH}\left(\mathrm{pH}_{\mathrm{e}}\right)$ of 7.4. Data from three cell-volume measurements obtained during this control phase $(15,10$, and $5 \mathrm{~min}$ before the experimental phase) were averaged, and all measurements, including the three baseline samples, were expressed as a percentage of the reference value thus obtained. This permitted the highlighting of volume changes/ constancy during the control phase as well as during experimental conditions. Unstable cell volume or an impaired cell viability (trypan blue exclusion) during the control phase led to discharge of the cells. In a control group, the $\mathrm{pH}_{\mathrm{e}}$ of the medium was maintained at 7.4 for $1 \mathrm{~h}(n=3)$. In four experimental groups, $\mathrm{pH}_{\mathrm{e}}$ was lowered from an initial 7.4 (control phase) to either 6.8, 6.6, 6.4, or 6.0 by addition of isotonic lactic acid $(350 \mathrm{mmol} / \mathrm{l})$ to the $\mathrm{HCO}_{3}^{-}$-buffered cell suspension (5-8 experiments/group). The required volumes of lactic acid were read from a titration curve determined beforehand. $\mathrm{CO}_{2}$ loss from buffering during acidosis was compensated for by increasing the $\mathrm{PCO}_{2}$ in the membrane oxygenator under control of medium $\mathrm{pH}$ and $\mathrm{PCO}_{2}(\mathrm{ABL}$
Radiometer, Copenhagen, Germany). Cell volume and viability were monitored for 25 min during lactacidosis. Osmolality was assessed under control conditions as well as after induction of lactacidosis (Osmomat 030, Gonotec). Respective experiments were repeated in HEPES-buffered medium (40 $\mathrm{mmol} / \mathrm{l})$ in the virtual absence of $\mathrm{HCO}_{3}^{-}(n=5-6$ /group). To verify the data from experiments with $\mathrm{BAE}$ cells, the study was also performed with human umbilical cord endothelial cells (HUVEC) at $\mathrm{pH} 6.4$ and $6.0\left(n=6\right.$ /group) in $\mathrm{HCO}_{3}^{-}-$ buffered media.

In the second part of the study, we focused on the mechanisms responsible for swelling using inhibitors of transport systems involved in $\mathrm{pH}_{\mathrm{i}}$ control: 5-( $N$-ethyl- $N$-isopropyl) amiloride (EIPA) hydrochloride was applied in a concentration of $50 \mu \mathrm{mol} / /$ to inhibit $\mathrm{Na}^{+} / \mathrm{H}^{+}$exchange in the virtual absence of $\mathrm{HCO}_{3}^{-}$(HEPES buffered) in experiments where $\mathrm{pH}_{\mathrm{e}}$ was reduced to 6.0. A concentration of $1 \mathrm{mmol} / \mathrm{l} \mathrm{DIDS}$ was used in the presence of $\mathrm{HCO}_{3}^{-}\left(25 \mathrm{mmol} / \mathrm{l}, 5 \% \mathrm{CO}_{2}\right)$ to inhibit $\mathrm{HCO}_{3}^{-}$transporters such as $\mathrm{Na}^{+}-\mathrm{HCO}_{3}^{-}$cotransport or $\mathrm{Cl}^{-} / \mathrm{HCO}_{3}^{-}$exchange, again during acidosis at $\mathrm{pH}_{\mathrm{e}}=6.0$. Ouabain $(1 \mathrm{mM})$ was used to inhibit $\mathrm{Na}^{+} / \mathrm{K}^{+}$exchange 1) during $45 \mathrm{~min}$ of baseline conditions at $\mathrm{pH}_{\mathrm{e}}=7.4$ and 2) during acidosis $\left(\mathrm{pH}_{\mathrm{e}}=6.0\right)$ after 10 min of pretreatment with ouabain to partially depolarize cells. In addition, experiments with acidosis at $\mathrm{pH}_{\mathrm{e}}=6.0$ were performed in $\mathrm{Na}^{+}$-free HEPES-buffered medium, where $\mathrm{NaCl}$ was replaced by choline chloride and $\mathrm{HCO}_{3}^{-}$by HEPES.

Statistics. Data are expressed as means $\pm \mathrm{SE}$. As a parametric test, a one-way repeated-measures analysis of variance (ANOVA) was used, and, as a nonparametric test, a repeated-measures ANOVA on ranks according to Friedman was used. Experimental groups were compared by ANOVA (Sigmastat, Jandel Scientific). Differences were considered significant if $P<0.05$.

\section{RESULTS}

Under control conditions, at $\mathrm{pH}=7.4$ and $37^{\circ} \mathrm{C}$, volume and viability of the BAE cells remained stable for up to $70 \mathrm{~min}$; longer periods were not studied. The average BAE cell volume was $1,232.3 \pm 19.2 \mu \mathrm{m}^{3}$ in $\mathrm{HCO}_{3}^{-}$-buffered medium. Titration of the suspension from $\mathrm{pH}_{\mathrm{e}}=7.4$ to $\mathrm{pH}_{\mathrm{e}}=6.8$ by isotonic lactic acid did not lead to a significant increase of cell volume (Fig. 1). Reduction of $\mathrm{pH}_{\mathrm{e}}$ to 6.6 caused mild swelling (102.9 \pm $2.2 \%$ of baseline volume) after $5 \mathrm{~min}$, followed by volume recovery.

Lowering of $\mathrm{pH}_{\mathrm{e}}$ to 6.4 or 6.0 , respectively, led to immediate cell swelling. The initial swelling after 3 $\min$ at $\mathrm{pH}_{\mathrm{e}}=6.4$ reached $106.7 \pm 5.6 \%$ of control. Maximal swelling $(107.0 \pm 2.2 \%)$ could be observed after $5 \mathrm{~min}$. An attempt to regulate cell volume was seen after the swelling maximum (Fig. 1), although a complete recovery of cell volume could not be found. At $10 \mathrm{~min}$ after onset of lactacidosis, cell volume had stabilized and remained at a constant level.

At $\mathrm{pH}_{\mathrm{e}}=6.0$, volume increased to $109.5 \pm 2.9 \%$ after $3 \mathrm{~min}$ and to a maximum of $111.7 \pm 4.0 \%$ after $5 \mathrm{~min}$. The cell-volume recovery was negligible, and volume remained at an increased level of $110.5 \pm 3.6 \%$ of control. Further reductions of $\mathrm{pH}_{\mathrm{e}}$ to 5.6 or 4.0 in individual experiments did not lead to further increases of cell volume, i.e., maximal swelling occurred at $\mathrm{pH}_{\mathrm{e}}=6.0$. However, at $\mathrm{pH}_{\mathrm{e}}$ levels below 6.0, cell 


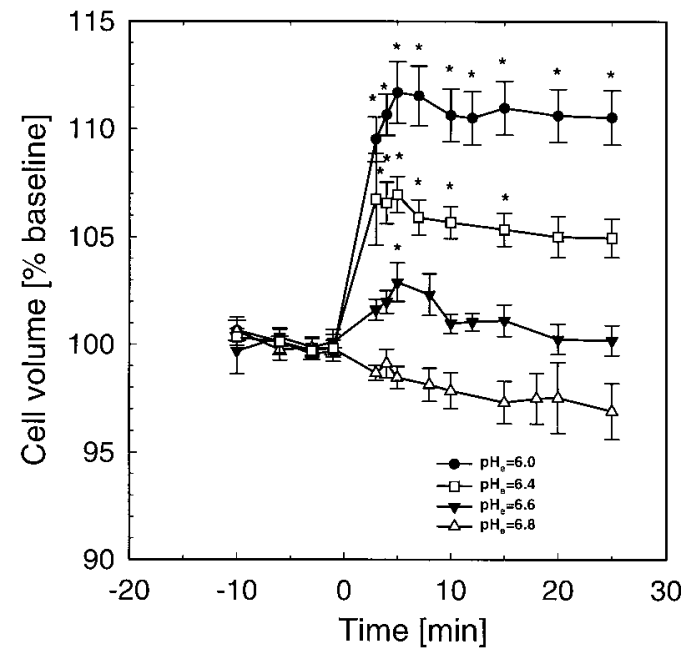

Fig. 1. Average cell-volume changes of bovine aortic endothelial (BAE) cells induced by changes of extracellular $\mathrm{pH}\left(\mathrm{pH}_{\mathrm{e}}\right)$ after administration of isotonic lactic acid to bicarbonate $\left(\mathrm{HCO}_{3}^{-}\right)$-buffered media. $\mathrm{pH}_{\mathrm{e}}$ was changed at time 0 after at least 15 min of incubation of the suspended cells at baseline conditions $\left(\mathrm{pH}_{\mathrm{e}}=7.4\right)$. Cell volumes are expressed as a percentage of the average of the 3 baseline measurements. ${ }^{*} P<0.05$ vs. baseline conditions.

viability decreased fast, which may have prevented the detection of further cell-volume increases.

Endothelial cells suspended in HEPES-buffered medium had a mean cell volume of $1,200.4 \pm 12.6{\mu \mathrm{m}^{3}}^{3}$, i.e., cells were only negligibly smaller than in $\mathrm{HCO}_{3}^{-}$buffered medium. In HEPES-buffered medium, lactacidosis again induced significant increases of cell volume if $\mathrm{pH}_{\mathrm{e}}$ was reduced to or below 6.6 (Fig. 2). During the whole observation period, swelling had approximately the same time course as in $\mathrm{HCO}_{3}^{-}$-buffered media, although the degree of swelling was significantly attenuated.

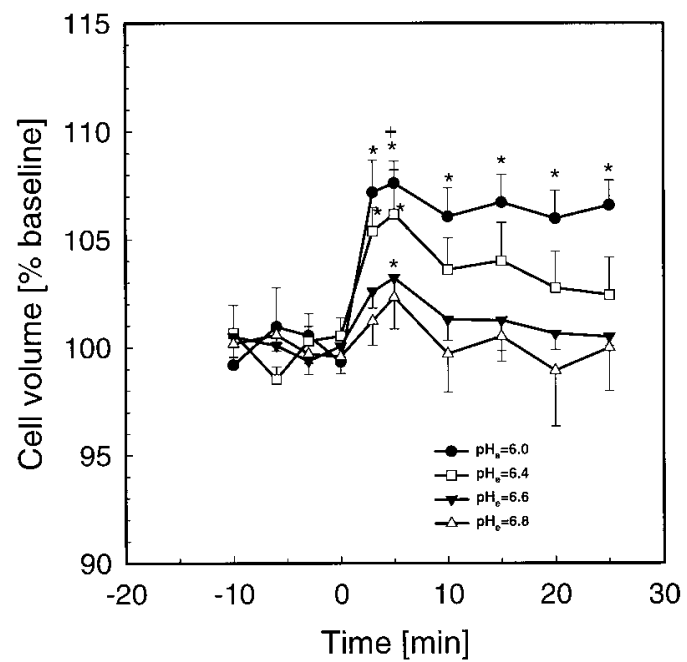

Fig. 2. Average cell-volume changes of BAE cells induced by changes of $\mathrm{pH}_{\mathrm{e}}$ after administration of isotonic lactic acid to HEPES-buffered media. $\mathrm{pH}_{\mathrm{e}}$ was changed at time 0 after at least 15 min of incubation of the suspended cells at baseline conditions $\left(\mathrm{pH}_{\mathrm{e}}=7.4\right)$. Cell volumes are expressed as a percentage of the average of the 3 baseline measurements. ${ }^{*} P<0.05$ vs. baseline conditions. $+P<$ 0.05 vs. $\mathrm{pH}_{\mathrm{e}}=6.8$.

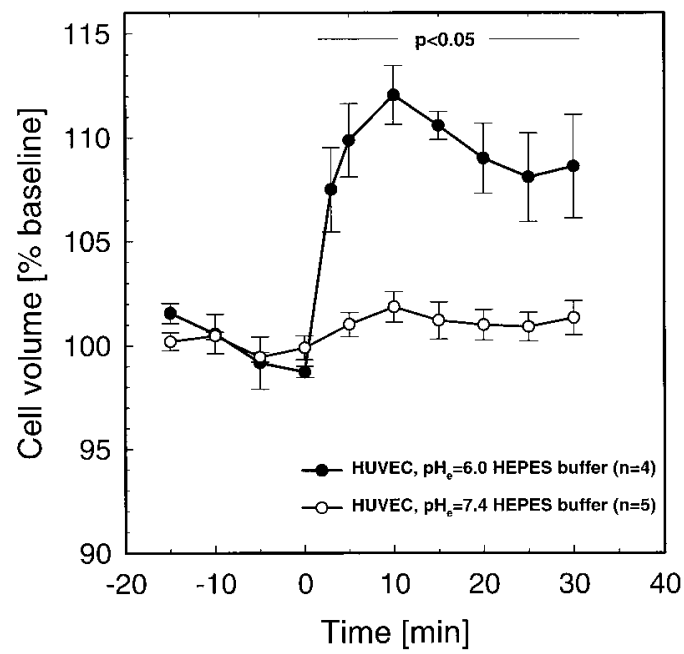

Fig. 3. Cell-volume changes of human umbilical cord endothelial cells (HUVEC) after reduction of $\mathrm{pH}_{\mathrm{e}}$ to 6.0 in $\mathrm{HCO}_{3}^{-}$-buffered media. $\mathrm{pH}_{\mathrm{e}}$ was changed by addition of isotonic lactic acid at time 0 after at least 15 min of incubation of the suspended cells at baseline conditions $\left(\mathrm{pH}_{\mathrm{e}}=7.4\right)$. Cell volumes are expressed as a percentage of the average of the 3 baseline measurements. In acidosis, all measurements were significantly elevated compared with physiological $\mathrm{pH}_{\mathrm{e}}$ $(P<0.05)$.

Experiments with HUVECs were in agreement with above observations (Fig. 3). Again, swelling occurred at $\mathrm{pH}_{\mathrm{e}} \leq 6.6$ (data not shown).

Inhibition of acidosis-induced endothelial cell swelling. In the absence of $\mathrm{HCO}_{3}^{-}$, the increase of cell volume at $\mathrm{pH}_{\mathrm{e}}=6.0$ could have been completely prevented if the cells had been pretreated with EIPA, the specific inhibitor of $\mathrm{Na}^{+} / \mathrm{H}^{+}$exchange (Fig. 4). Under baseline conditions, the presence of EIPA had no effect on cell volume.

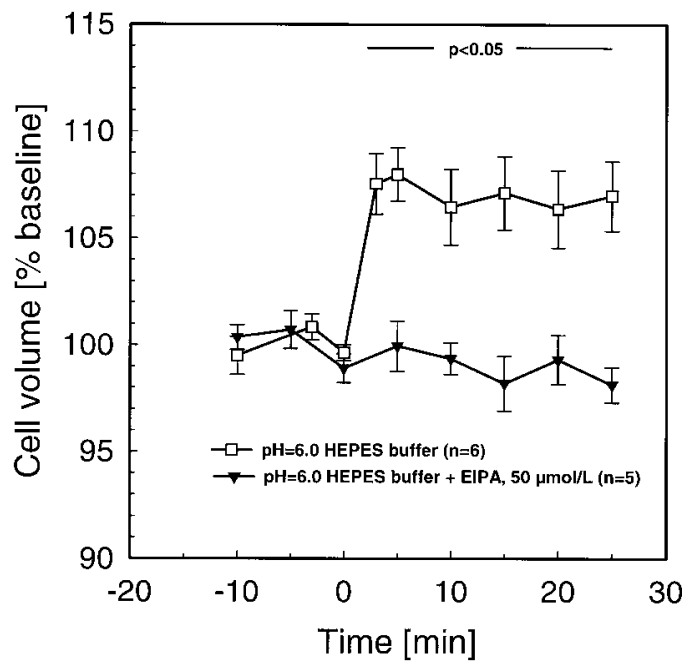

Fig. 4. Effect of ethylisopropylamiloride (EIPA) on cell swelling of BAE cells in HEPES-buffered media. Suspensions were pretreated with EIPA ( $50 \mu \mathrm{mol} / \mathrm{l}) 15 \mathrm{~min}$ before administration of lactic acid $(\mathbf{v})$. Compared with data from the untreated group ( $\square$ ), the acidosisinduced cell-volume increase could be completely prevented. Besides, EIPA had no effect proper on cell volume or viability during the control period. 


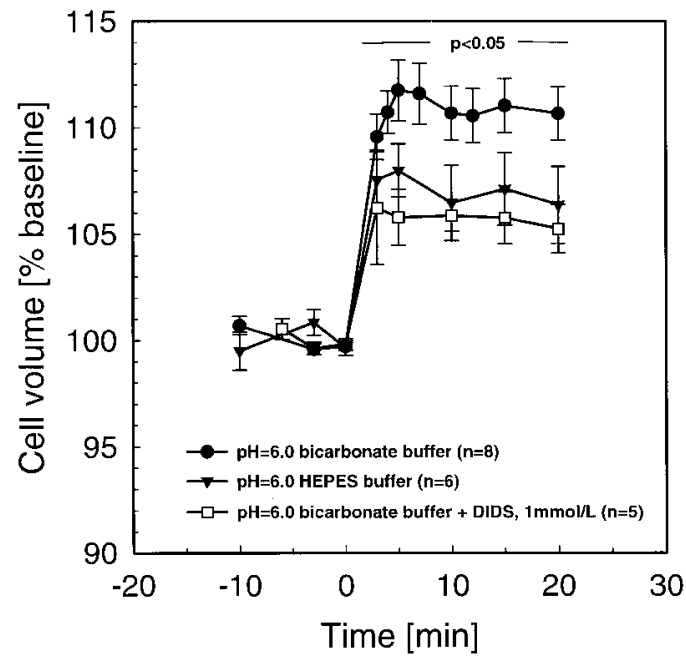

Fig. 5. Changes in BAE cell volume after lactic acid administration to a level of $\mathrm{pH}_{\mathrm{e}}=6.0$ in the presence ( $\square$ ) and absence ( $\bullet$ ) of DIDS (1 $\mathrm{mmol} / \mathrm{l})$ in $\mathrm{HCO}_{3}^{-}$-buffered media. The data obtained in the group pretreated with DIDS were similar to those obtained in HEPESbuffered medium in the absence of DIDS $\left(\mathrm{HCO}_{3}^{-}\right.$free; $\left.\mathbf{v}\right)$.

As indicated by Fig. 5, addition of DIDS, an inhibitor of $\mathrm{Cl}^{-} / \mathrm{HCO}_{3}^{-}$countertransport and $\mathrm{Na}^{+}-\mathrm{HCO}_{3}^{-}$cotransport, did not fully block cell swelling in $\mathrm{HCO}_{3}^{-}$ buffered media. Interestingly, in the presence of DIDS, the remaining volume response to lactacidosis was very similar to that observed in HEPES-buffered medium without DIDS pretreatment (Fig. 5).

These findings suggests that $\mathrm{Na}^{+}$and $\mathrm{HCO}_{3}^{-}$transport across the cell membrane are the main factors responsible for acidosis-induced endothelial swelling. Further evidence supporting this view came from experiments in $\mathrm{Na}^{+}$-free medium (Fig. 6). $\mathrm{Na}^{+}$and $\mathrm{HCO}_{3}^{-}$were replaced by choline chloride and HEPES under strict maintenance of isotonicity. This by itself was found to cause a progressive, gradual decrease of

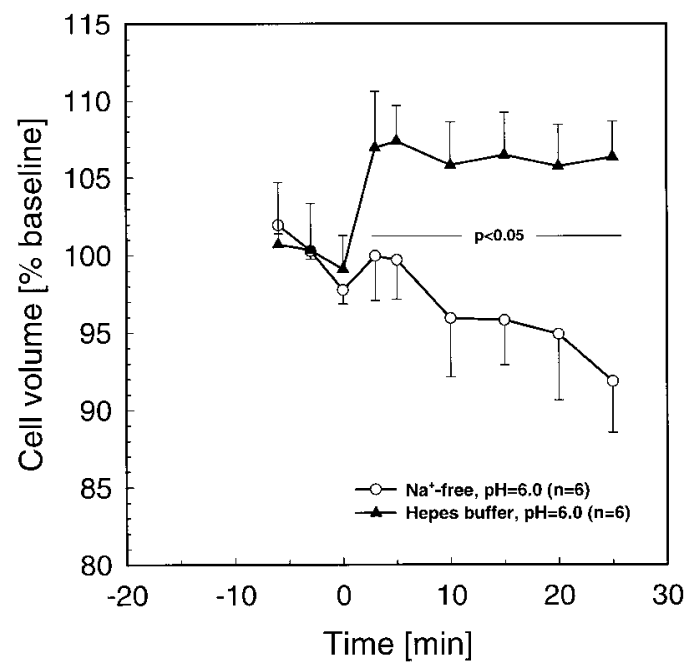

Fig. 6. Kinetics of BAE cell swelling in the presence and absence of $\mathrm{Na}^{+}$. Compared with HEPES-buffered media (i.e., $\mathrm{HCO}_{3}^{-}$free; $\mathbf{\Delta}$ ), acidosis-induced cell swelling was nearly absent in $\mathrm{Na}^{+}-$and $\mathrm{HCO}_{3}^{-}$free medium $(\circ)$.

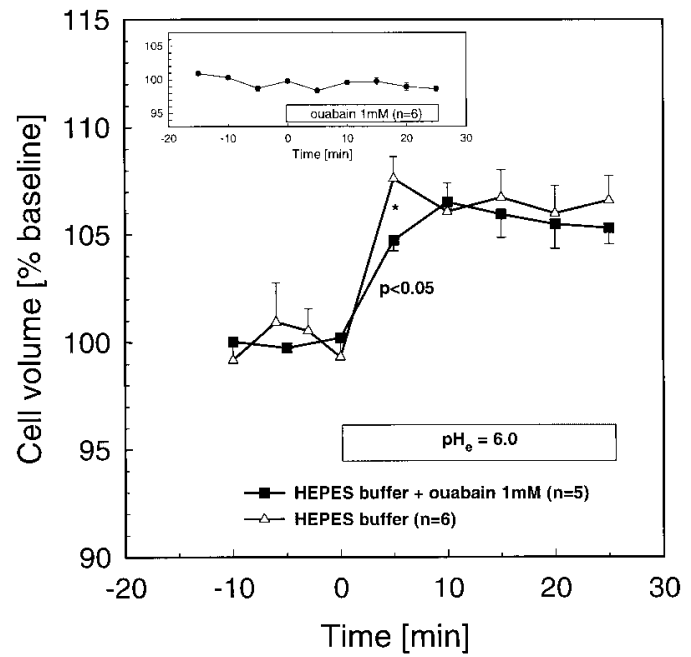

Fig. 7. Effects of ouabain on acidosis-induced swelling of BAE cells in HEPES-buffered media $\left(\mathrm{pH}_{\mathrm{e}}=6.0 ; \mathbf{a}\right)$. Ouabain was added to the cells 10 min before acidosis induction. $\triangle$, data obtained in the absence of ouabain. Swelling kinetics are slowed in the presence of ouabain. Inset: baseline cell volume was unaffected by ouabain at physiological $\mathrm{pH}\left(\mathrm{pH}_{\mathrm{e}}=7.4\right)$.

cell volume, probably because of outward leakage of intracellular $\mathrm{Na}^{+}$down the concentration gradient. As shown in Fig. 6, virtually no swelling was found at lactacidosis of $\mathrm{pH}_{\mathrm{e}}=6.0$ in the absence of $\mathrm{Na}^{+}$.

In an effort to affect membrane potential and intracellular $\mathrm{Na}^{+}$concentrations, cells were pretreated by ouabain. As shown in Fig. 7, the degree of swelling in HEPES-buffered media was unaffected by ouabain. Swelling kinetics, however, appeared slowed down because the swelling maximum was reached after $10 \mathrm{~min}$ only. Ouabain did not affect cell volume during baseline conditions $\left(\mathrm{pH}_{\mathrm{e}}=7.4\right.$; Fig. 7 , inset $)$.

\section{DISCUSSION}

The data accumulated herein indeed confirm former in vivo observations that extracellular acidosis may promote endothelial swelling (15). To understand the mechanisms of endothelial swelling, we have to assume the following sequence of events.

Extracellular acidosis leads to an influx of acid equivalents into the cell as described for astrocytes (12, $17,18,20,22)$. The degree of acidosis studied here is within a range expected to occur in the parenchyma of heart (21), muscle (25), or brain (reviewed in Ref. 12) during ischemia. In $\mathrm{HCO}_{3}^{-} / \mathrm{CO}_{2}$-buffered media, a fast acid entry is likely. It is caused by $\mathrm{CO}_{2}$ influx, which diffuses easily through the cell membrane, forming carbonic acid and subsequently $\mathrm{H}^{+}$and $\mathrm{HCO}_{3}^{-}$in the cytosol. The electrochemical gradient for $\mathrm{H}^{+}$favors the development of cytosolic acidosis already at physiological $\mathrm{pH}_{\mathrm{e}}$ levels. Hence, a normal $\mathrm{pH}_{\mathrm{i}}$ can only be maintained by active $\mathrm{pH}$ regulation involving ion transporters, ion channels, and metabolic processes.

Under $\mathrm{CO}_{2} / \mathrm{HCO}_{3}^{-}$-free conditions, the situation is more complex. One might expect enhanced intracellular acidosis compared with baseline conditions, because the cells are $\mathrm{HCO}_{3}^{-}$depleted. However, because 
$\mathrm{CO}_{2}$ diffusion over the cell membrane is thought to be the major mechanism of intracellular acidification, omission of $\mathrm{CO}_{2} / \mathrm{HCO}_{3}^{-}$may rather result in an attenuated intracellular acidosis, as seen in glial cells (20).

The observed swelling is assumed to result from $\mathrm{pH}_{\mathrm{i}}$ regulatory systems such as NHE: the uptake of $\mathrm{Na}^{+}$in exchange for $\mathrm{H}^{+}$, which comes from intracellular buffers and is therefore thought to be osmotically inactive (3), increases the osmotic load of the cell and is followed by influx of water. Inhibition of NHE either by EIPA (Fig. 4) or the absence of $\mathrm{Na}^{+}$(Fig. 6) hence prevents swelling in $\mathrm{HCO}_{3}^{-}$-free media. The use of ouabain to partially depolarize the cells results in a delay or slowdown of the swelling response (Fig. 7). This presumably is related to a gradual rise in intracellular $\mathrm{Na}^{+}$, which suppresses $\mathrm{Na}^{+}$entry through the NHE.

In the presence of $\mathrm{HCO}_{3}^{-}$, other $\mathrm{pH}_{\mathrm{i}}$ regulatory transport systems are activated in extracellular acidosis in addition to $\mathrm{NHE}$, i.e., $\mathrm{Na}^{+}-\mathrm{HCO}_{3}^{-}$cotransport or NCBE: an involvement of $\mathrm{HCO}_{3}^{-}$-dependent transport processes is suggested by the larger volume increases seen in $\mathrm{HCO}_{3}^{-}$-containing compared with HEPES-buffered media (Figs. 1 and 2) and by the reduction of swelling in DIDS-treated cells to the level seen in the absence of $\mathrm{HCO}_{3}^{-}$(Fig. 5). $\mathrm{HCO}_{3}^{-}$-dependent transporters so far have not been discussed with respect to endothelial swelling, although their participation in the regulation of endothelial $\mathrm{pH}_{\mathrm{i}}$ is known $(1,2,4,10)$; at physiological $\mathrm{pH}_{\mathrm{e}}, \mathrm{HCO}_{3}^{-}$-dependent transport systems contribute more to $\mathrm{pH}_{\mathrm{i}}$ homeostasis than NHE. In most cell types, the contribution of NHE to $\mathrm{pH}_{\mathrm{i}}$ homeostasis increases with decreasing $\mathrm{pH}_{\mathrm{i}}(4,24)$.

It remains to be determined whether NCBE or $\mathrm{Na}^{+}-$ $\mathrm{HCO}_{3}^{-}$cotransport is responsible for $\mathrm{HCO}_{3}^{-}$-dependent swelling, because both are present in endothelium $(1,2$, $4,10)$. NCBE, however, is less likely to be involved in the swelling response, because uptake of $\mathrm{HCO}_{3}^{-}$by this transporter and the ensuing buffering of protons generates $\mathrm{CO}_{2}$, which can readily leave the cell. Because $\mathrm{Cl}^{-}$is exported in exchange for $\mathrm{HCO}_{3}^{-}$, this would imply rather a loss of osmotic activity and, hence, cell shrinkage. $\mathrm{Na}^{+}-$ $\mathrm{HCO}_{3}^{-}$cotransport, on the other hand, imports $\mathrm{Na}^{+}$as osmotically active particles together with $\mathrm{HCO}_{3}^{-}$and, therefore, better explains the observed swelling response. $\mathrm{Na}^{+}-\mathrm{HCO}_{3}^{-}$cotransport is electrogenic and can function only if membrane potential permits.

In glial cells, despite the activation of $\mathrm{pH}_{\mathrm{i}}$ regulatory mechanisms after induction of extracellular acidosis, $\mathrm{pH}_{\mathrm{i}}$ does not normalize $(17,18,20)$. With ongoing $\mathrm{pH}_{\mathrm{i}}$ regulation, one would assume cell swelling to continue until $\mathrm{pH}_{\mathrm{i}}$ has normalized. Because swelling kinetics are similar in endothelial cells (Figs. 1-3) and glia $(12,22)$ (cells swell on acidification with cell volume, reaching a new steady state after a few minutes), it is quite likely that endothelium is likewise acidified in extracellular acidosis. This has to be verified in future experiments. Mellergard et al. $(17,18)$ offered three possible explanations for the failing $\mathrm{pH}_{\mathrm{i}}$ regulation at reduced extracellular $\mathrm{pH}$ in astroglia: 1) $\mathrm{pH}_{\mathrm{i}}$ is not the regulated parameter, 2) the $\mathrm{H}^{+}$ extrusion capacity is reduced, and 3$) \mathrm{H}^{+}$leak fluxes are too high. As an explanation, they favored a reduced acid-extrusion capacity by competitive inhibition of the NHE by extracellular protons.

Likewise unexplained so far is the observation that cell swelling ceases at a given plateau in glia (12, 20, 22) as well as in endothelium (Figs. 1 and 2), particularly if $\mathrm{pH}_{\mathrm{i}}$ does not normalize (20). Under these conditions, $\mathrm{pH}_{\mathrm{i}}$ regulatory mechanisms and swelling would be expected to continue ion transport until $\mathrm{pH}_{\mathrm{i}}$ normalizes. A possible explanation might involve an opening of volume-regulated anion channels once cell volume increases (19), which would render cell membranes more permeable for $\mathrm{Cl}^{-}, \mathrm{HCO}_{3}^{-}$, and lactate. Recently, Voets et al. (23) elegantly demonstrated that a decrease of intracellular ionic strength rather than an increase of cell volume triggers the opening of such channels, at least in conditions such as hyposmotic endothelial swelling. All processes of the current project were studied in strict isotonicity, which, therefore, makes an involvement of volume-regulated anion channels less likely.

Another possible explanation would be the recently described control of NHE1 activity by an intracellular $\mathrm{Na}^{+}$receptor (7). That receptor is thought to provide a general mechanism for regulating the intracellular $\mathrm{Na}^{+}$concentration in epithelia, where its activation reduces NHE1 activity. In nonepithelial cells, NHE has also been reported to be inhibited by increased intracellular $\mathrm{Na}^{+}$concentration (6). Inhibition of NHE would reduce $\mathrm{Na}^{+}$influx and, hence, cell swelling and could explain the plateau phase observed at all levels of acidosis tested. The experiments employing ouabain to partially depolarize cells, however, only yielded a slowdown of the swelling response but did not affect the plateau phase. Inhibition of $\mathrm{Na}^{+}-\mathrm{K}^{+}$-ATPase by ouabain was presumably followed by a gradual increase of intracellular $\mathrm{Na}^{+}$and should thereby inhibit NHE (and swelling) via activation of the intracellular $\mathrm{Na}^{+}$receptor (7) earlier than in the absence of ouabain. This did not occur. Hence, further experiments including measurements of $\mathrm{pH}_{\mathrm{i}}$ are required to verify details of the mechanisms of the swelling response in extracellular acidosis.

In conclusion, endothelial swelling in extracellular lactacidosis is a result of an activation of ion transport systems involved in $\mathrm{pH}_{\mathrm{i}}$ regulation, in particular, $\mathrm{NHE}$ and $\mathrm{Na}^{+}-\mathrm{HCO}_{3}^{-}$cotransport. Under in vivo conditions, acidosis-induced endothelial swelling may hamper microcirculatory blood flow. Drugs that interfere with $\mathrm{pH}_{\mathrm{i}}$ regulation can prevent the swelling response and, hence, may positively affect postischemic microcirculation.

The excellent technical assistance of Barbara Kempski and Angelica Karpi is gratefully acknowledged.

This paper contains data from the doctoral thesis of S. Behmanesh.

\section{REFERENCES}

1. Bonnano JA and Giasson C. Intracellular $\mathrm{pH}$ regulation in fresh and cultured bovine corneal endothelium. I. Na ${ }^{+} / \mathrm{H}^{+}$exchange in the absence and presence of $\mathrm{HCO}_{3}^{-}$. Invest Opthalmol Vis Sci 33: 3058-3067, 1992. 
2. Bonnano JA and Giasson C. Intracellular $\mathrm{pH}$ regulation in fresh and cultured bovine corneal endothelium. I. $\mathrm{Na}^{+}: \mathrm{HCO}_{3}^{-}$ cotransport and $\mathrm{Cl}^{-} / \mathrm{HCO}_{3}^{-}$exchange. Invest Opthalmol Vis Sci 33: 3068-3079, 1992.

3. Cala PM, Anderson SE, and Cragoe EJ. Na/H exchangedependent cell volume and $\mathrm{pH}$ regulation and disturbances. Comp Biochem Physiol A Physiol 90: 551-555, 1988.

4. Faber S, Lang HJ, Hock FJ, Schölkens BA, and Mutschler E. Intracellular $\mathrm{pH}$ regulation in bovine aortic endothelial cells: evidence of both $\mathrm{Na}^{+} / \mathrm{H}^{+}$exchange and $\mathrm{Na}^{+}$-dependent $\mathrm{Cl}^{-} /$ $\mathrm{HCO}_{3}^{-}$exchange. Cell Physiol Biochem 8: 202-211, 1998.

5. Förstermann U, Pollock JS, Schmidt HHH, Heller M, and Murad F. Calmodulin-dependent endothelium-derived relaxing factor/nitric oxide synthase activity is present in the particulate and cytosolic fractions of bovine aortic endothelial cells. Proc Natl Acad Sci USA 99: 1788-1792, 1991.

6. Grinstein S, Cohen $\mathbf{S}$, and Rothstein A. Cytoplasmic $\mathrm{pH}$ regulation in thymic lymphocytes by an amiloride-sensitive $\mathrm{Na}+/ \mathrm{H}+$ antiport. J Gen Physiol 83: 341-369, 1984.

7. Ishibashi H, Dinudom A, Harvey KF, Kumar S, Young JA, and Cook DI. $\mathrm{Na}^{+}-\mathrm{H}^{+}$exchange in salivary secretory cells is controlled by an intracellular $\mathrm{Na}^{+}$receptor. Proc Natl Acad Sci USA 96: 9949-9953, 1999.

8. Jaffe EA, Nachman RL, Becker CG, and Minick CR. Culture of human endothelial cells derived from umbilical veins. Identification of morphologic and immunological criteria. J Clin Invest 11: 2745-2756, 1973.

9. Jakubovicz DE and Klip A. Lactic acid-induced swelling in C6 glial cells via $\mathrm{Na}^{+} / \mathrm{H}^{+}$exchange. Brain Res 48: 215-224, 1989.

10. Jentsch TJ, Korbmacher C, Janicke I, Fischer DG, Stahl F, Helbig H, Hollwede H, Cragoe EJ, Keller SK, and Wiederholt M. Regulation of cytoplasmic $\mathrm{pH}$ of cultured bovine corneal endothelial cells in the absence and presence of bicarbonate. J Membr Biol 103: 29-40, 1988.

11. Kempski O, Spatz M, Valet G, and Baethmann A. Cell volume regulation of cerebrovascular endothelium in vitro. J Cell Physiol 123: 51-54, 1985.

12. Kempski O, Staub F, Jansen M, Schödel F, and Baethmann A. Glial swelling during extracellular acidosis in vitro. Stroke 19: 385-392, 1988.

13. Kempski O, Zimmer M, Neu A, von Rosen F, Jansen M, and Baethmann A. Control of glial cell volume in anoxia. In vitro studies on ischemic cell swelling. Stroke 18: 623-628, 1987.
14. Kretschmar K and Engelhardt T. Swelling of capillary endothelial cells contributes to traumatic hemorrhagic shock-induced microvascular injury: a morphologic and morphometric analysis. Int J Mircocirc Clin Exp 14: 45-49, 1994.

15. Mazzoni MC, Cragoe EJ, and Arfors KE. Systemic blood acidosis in low-flow ischemia induces capillary luminal narrowing. Int J Microcirc Clin Exp 14: 144-150, 1994.

16. Mazzoni MC, Intaglietta M, Cragoe EJ, and Arfors KE. Amiloride-sensitive $\mathrm{Na}^{+}$pathways in capillary endothelial swelling during hemorrhagic shock. J Appl Physiol 73: 14671473, 1992.

17. Mellergard P, Ouyang Y, and Siesjö BK. Relationship between intra- and extracellular $\mathrm{pH}$ in primary cultures of rat astrocytes. Am J Physiol Cell Physiol 267: C581-C589, 1994.

18. Mellergard $\mathbf{P}$ and Siesjö BK. Astrocytes fail to regulate intracellular $\mathrm{pH}$ at moderately reduced extracellular $\mathrm{pH}$. Neuroreport 2: 695-698, 1991.

19. Nilius B, Prenen J, and Droogmans G. Modulation of volume-regulated anion channels by extra- and intracellular $\mathrm{pH}$. Pflügers Arch 436: 742-748, 1998.

20. Plesnila N, Haberstock J, Peters J, Kölbl I, Baethmann A, and Staub F. Effect of lactacidosis on cell volume and intracellular $\mathrm{pH}$ of astrocytes. J Neurotrauma 16: 831-841, 1999.

21. Soares PR, deAlbuquerque CP, Chako VP, Gerstenblith G, and Weiss RG. Role of preischemic glycogen depletion in the improvement of postischemic metabolic and contractile recovery of ischemia-precondiitioned rat hearts. Circulation 96: 975-983, 1997.

22. Staub F, Baethmann A, Peters J, Weigt H, and Kempski O. Effects of lactacidosis on glial cell volume and viability. J Cereb Blood Flow Metab 10: 866-876, 1990.

23. Voets T, Droogmans G, Rasjin G, Eggermont J, and Nilius B. Reduced intracellular ionic strength as the initial trigger for activation of endothelial volume-regulated anion channels. Proc Natl Acad Sci USA 96: 5298-5303, 1999.

24. Volk C, Albert T, and Kempski OS. A proton-translocating $\mathrm{H}^{+}$-ATPase is involved in $\mathrm{C} 6$ glial $\mathrm{pH}$ regulation. Biochim Biophys Acta 1372: 28-36, 1998.

25. Yan GX and Kleber AG. Changes in extracellular and intracellular $\mathrm{pH}$ in ischemic rabbit papillary muscle. Circ Res 71: 460-470, 1992. 